\section{Elevated Temperature Greatly Improves Trans- formation of Fresh and Frozen Competent Cells in Yeast}

BioTechniques 28:___(May 2000)

Transformation with plasmids is a standard method for yeast genetics and molecular biology. Yeast transformation by a $\mathrm{Li}^{+}$-mediated method (8) was improved by changing several parameters, including the addition of carrier DNA, alterations of cell growth conditions or cell density and the addition of several reagents $(6,7,9,11)$. In contrast to these efficient transformation protocols, simple transformation procedures without careful preparation or with cells streaked on a plate have been described. Some of the simplified transformation procedures developed so far, however, required a long incubation time (5) or an expensive reagent (3) for high transformation efficiency, or others gave a low efficiency $(2,13)$. By investigating several factors affecting the transformation efficiency, we found that the length of the $42^{\circ} \mathrm{C}$ incubation time of the cell/DNA/polyethylene glycol (PEG)/Li-mixture significantly influenced transformation efficiency of cells on a streaked plate. A simple preparation procedure for frozen competent cells with high transformation efficiency was also developed.

The budding yeast strain W303-1A (MATa ade2-1 can1-100 ura3-1 leu23,112 trp1-1 his3-11,15) and the fission yeast (No. 22: $h^{-}$leul-32) were used. Plasmids used were pRS316 (URA3 and CEN/ARS) (12) and pREP1 (LEU2 and $\operatorname{arsl}$ ) (10) for the budding and fission yeast, respectively. Yeast cells were grown on yeast extract/peptone/ dextrose (YPD) agar plates for one or two days.

For the transformation procedure, cells were transferred with a toothpick or spatula into a tube containing PLATE solution [40\% PEG4000 (Katayama Chemical, Osaka, Japan), 0.1 M lithium acetate, $10 \mathrm{mM}$ Tris- $\mathrm{HCl}(\mathrm{pH} 7.5)$ and $1 \mathrm{mM}$ EDTA] according to Elble (5), or PLAG solution (PLATE solution
Table 1. Transformation of Frozen Competent Cells Prepared by the Simple Method

\begin{tabular}{|ccc|}
\hline $\begin{array}{c}\text { Days of } \\
\text { Storage }\end{array}$ & PLATE & PLAG \\
\hline 0 & 4628 & 4476 \\
7 & 1636 & 4000 \\
14 & 1330 & 6186 \\
60 & 2660 & 4720 \\
\hline
\end{tabular}

$3.2 \times 10^{8}$ cells (W303-1A) were suspended in $1 \mathrm{~mL}$ of PLATE or PLAG solutions. The suspensions were mixed with $20 \mu \mathrm{L} 10 \mathrm{mg} / \mathrm{mL}$ carrier RNA. Aliquots $(200 \mu \mathrm{L})$ were placed in a $-80^{\circ} \mathrm{C}$ freezer. After the indicated number of days, the frozen competent cells were thawed, mixed with $1 \mu \mathrm{L} 1 \mu \mathrm{g} / \mu \mathrm{L}$ pRS316 plasmid DNA, incubated at $42^{\circ} \mathrm{C}$ for $2 \mathrm{~h}$ and spread on selective plates.

containing $15 \% \mathrm{v} / \mathrm{v}$ glycerol). The suspension was mixed with a $1 / 10-1 / 50$ volume of $10 \mathrm{mg} / \mathrm{mL}$ carrier RNA or DNA. The carrier RNA was prepared by the conventional alkaline lysis method (1) from E. coli lacking a plasmid. RNA was precipitated by adding an equal volume of $5 \mathrm{M} \mathrm{LiCl}$ and dissolved in TE buffer [10 mM Tris- $\mathrm{HCl}(\mathrm{pH} 7.5)$ and 1 mM EDTA]. The carrier RNA gave more reproducible results than carrier DNA $(5,11)$ in our experience. For preparing frozen cells, the suspensions were placed directly in a $-80^{\circ} \mathrm{C}$ freezer. Dry ice and flash cooling were not used. Aliquots of the cell/PLATE mixture or the frozen cell/PLAG mixture thawed by hand were mixed with plasmid DNA, mixed vigorously for $10 \mathrm{~s}$ and incubated at $42^{\circ} \mathrm{C}$. The mixtures were spread directly on selective plates. For spreading low volumes easily, an appropriate amount of sterile water was added before spreading.

We confirmed the effectiveness of Elble's procedure (5) and found that longer incubation times at $42^{\circ} \mathrm{C}$ greatly enhanced the transformation efficiency of yeast (Figure 1). The highest transformation efficiency was obtained by incubation at $42^{\circ} \mathrm{C}$ for $2 \mathrm{~h}$ with the budding yeast and $4 \mathrm{~h}$ with the fission yeast
(No. 22: $h^{-}$leu1-32). This effect was observed with four additional Saccharomyces cerevisiae strains. A high concentration of cells $\left(>5 \times 10^{8}\right.$ cells $\left./ \mathrm{mL}\right)$ was important for efficient transformation, and there was no negative effect on transformation efficiency with very high cell concentrations $\left(>10^{10}\right.$ cells $/ \mathrm{mL}$ ) (data not shown).

The simple transformation procedure was applied for frozen competent cells at $-80^{\circ} \mathrm{C}$. Competent cells stored for 60 days at $-80^{\circ} \mathrm{C}$ in PLAG solution did not show a decrease in transformation efficiency (Table 1). Carrier RNA or DNA could be added before freezing. The preparation procedure for frozen competent cells was easy compared to the published procedure (4).

Schiestl and Gietz (11) reported that the best transformation efficiency was obtained with a 15-min heat shock at $42^{\circ} \mathrm{C}$. When competent cells were prepared using the careful procedure of Gietz et al. (6), extension of the $42^{\circ} \mathrm{C}$ incubation time did not result in a significant enhancement of transformation efficiency. Increased permeability of the cells prepared by the simple method may be necessary for efficient transformation. This additional damage can be

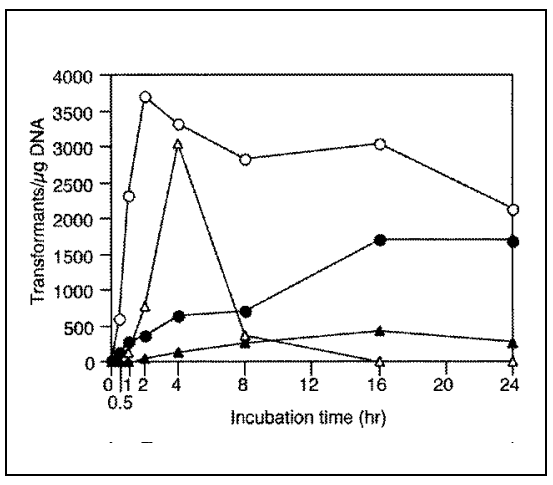

Figure 1. Effect of $42^{\circ} \mathrm{C}$ incubation time in PLATE on transformation efficiency. Cells of the budding yeast (W303-1A) and the fission yeast (No. 22) were grown on YPD plates and suspended in PLATE solution at a concentration of 1.6 and $2.5 \times 10^{8}$ cells $/ \mathrm{mL}$, respectively. The budding yeast suspension was mixed with $10 \mathrm{mg} /$ $\mathrm{mL}$ carrier RNA to a final concentration of $1 \mathrm{mg} /$ $\mathrm{mL}$ and $\mathrm{pRS} 316$, and the fission yeast suspension was mixed with pREP1 without carrier. Aliquots $(200 \mu \mathrm{L})$ of these suspensions containing $1 \mu \mathrm{g}$ plasmid DNA were incubated at $42^{\circ} \mathrm{C}$ or $30^{\circ} \mathrm{C}$ and plated on selective plates. Circles and triangles represent the results from $S$. cerevisiae and Schizosaccharomyces pombe, respectively, and open and closed symbols represent incubation temperature at $42^{\circ} \mathrm{C}$ and $30^{\circ} \mathrm{C}$, respectively. 
achieved by a few days incubation at room temperature (5) or 2-4 h incubation at $42^{\circ} \mathrm{C}$ in the cell/PEG/Li-mixture.

\section{REFERENCES}

1.Ausubel, F., R. Brent, R.E. Kingston, D.D. Moore, J.G. Seidman, J.A. Smith and K. Struhl. 1995. Short Protocols in Molecular Biology, 3rd ed., John Wiley \& Sons, New York.

2.Baker, R. 1991. Rapid colony transformation of Saccharomyces cerevisiae. Nucleic Acids Res. 19:1945.

3.Chen, D., B. Yang and T. Kuo. 1992. Onestep transformation of yeast in stationary phase. Curr. Genet. 21:83-84.

4.Dohmen, R.J., A.W. Strasser, C.B. Honer and C.P. Hollenberg. 1991. An efficient transformation procedure enabling long-term storage of competent cells of various yeast genera. Yeast 7:691-692.

5.Elble, R. 1992. A simple and efficient procedure for transformation of yeasts. BioTechniques 13:18-20.

6.Gietz, R.D., R.H. Schiestl, A.R. Willems and R.A. Woods. 1995. Studies on the transformation of intact yeast cells by the LiAc/SSDNA/PEG procedure. Yeast 11:355-360.

7.Hill, J., K.A.I.G. Donald and D.E. Griffiths. 1991. DMSO-enhanced whole cell yeast transformation. Nucleic Acids Res. 19:5791.

8.Ito, H., Y. Fukuda, K. Murata and A. Kimura. 1983. Transformation of intact yeast cells treated with alkali cations. J. Bacteriol. 153:163-168.

9.Lauermann, V. 1991. Ethanol improves the transformation efficiency of intact yeast cells. Curr. Genet. 20:1-3.

10.Maundrell, K. 1993. Thiamine-repressible expression vectors $\mathrm{pREP}$ and $\mathrm{pRIP}$ for fission yeast. Gene 123:127-130.

11.Schiestl, R.H. and R.D. Gietz. 1989. High efficiency transformation of intact yeast cells using single stranded nucleic acids as a carrier. Curr. Genet. 16:339-346.

12.Sikorski, R.S. and P. Hieter. 1989. A system of shuttle vectors and yeast host strains designed for efficient manipulation of DNA in Saccharomyces cerevisiae. Genetics 122:1927.

13.Soni, R., J.P. Carmichael and J.A.H. Murray. 1993. Parameters affecting lithium acetate-mediated transformation of Saccharomyces cerevisiae and development of a rapid and simplified procedure. Curr. Genet. 24:455-459.

We thank members of our laboratory for confirming the reliability of the method. We also thank Dr. Janet Kurjan for critical reading of the manuscript. Address correspondence to Rinji Akada, Department of Applied Chemistry and Chemical Engineering, Faculty of Engineering, Yamaguchi University, Ube 755-8611, Japan. Internet: rinji@po.cc.yamaguchi-u.ac.jp
Received 13 September 1999; accepted 24 January 2000.

\section{Rinji Akada, Miho Kawahata and Yoshinori Nishizawa Yamaguchi University Ube, Japan}

\section{Microdissection by Exclu- sion and DNA Extraction for Multiple PCR Analy- ses from Archival Tissue Sections}

BioTechniques 28:____ (May 2000)

The study of genetic alterations is a crucial facet of human cancer research. However, the molecular analysis of genetic changes has been limited by the diversity of cell types present in specimens. The genomic DNA present in non-neoplastic cells may complicate the results of molecular analysis depending on the ratio of neoplastic to non-neoplastic genomic DNA and the sensitivity of the assays.

With the development of PCR technology that can amplify small quantities of DNA, several kinds of microdissection-based methods have been established. One category uses ablation with UV radiation to destroy or remove the unwanted regions, with the remaining target tissue then collected mechanically (7). The possibility of damage to the target DNA is the main disadvantage of this method. A second category uses a hand-held tool to separate cells of interest from the histologic section. The tool can be a pipet (11), micropipet tip (10), needle (4), blade (5) or adhesive gum (8) that is either hand-held or connected to a micromanipulator arm (6). These techniques are not sufficiently precise to allow microdissection of diffuse tumors because internal stromal cells are generally not discarded, and so the ratio of tumor cells to normal cells is not optimized. A third category uses a laser-based technique called laser capture microdissection (3) or UV laser microbeam (1), but this sophisticated method is quite costly and not accessible to all laboratories.

We present here a protocol for microdissection of archival paraffin-embedded tissue using a manual approach based on the exclusion of unwanted normal cells and followed by DNA extraction. This procedure allows 8-10 reactions to be routinely performed on lesions as small as $1 \mathrm{~mm}$ in diameter, even in cases of diffuse tumor infiltration. Its application will be demonstrated in the study of loss of heterozygosity (LOH) on chromosome 18q.

Sections of formalin-fixed, paraffinembedded tissues were cut at $7 \mu \mathrm{m}$, collected on clean untreated glass slides, deparaffinized twice with xylene and rinsed twice with methanol. The first section was stained with hematoxylin and eosin and used for 